\title{
Haemodynamic effects of nifedipine and propranolol in patients with hypertrophic obstructive cardiomyopathy
}

\author{
KNUD LANDMARK, SVEIN SIRE, ERIK THAULOW, JAN P AMLIE, SIGURD \\ NITTER-HAUGE \\ From Medical Department B, Rikshospitalet, University Clinic, Oslo, Norway
}

SUMMARY The haemodynamic effects of nifedipine, propranolol, and the combined administration of the two drugs were studied in 12 patients with hypertrophic obstructive cardiomyopathy. The combined administration of nifedipine and propranolol appeared to be superior to that of nifedipine alone. The spontaneous heart rate was reduced in most cases after nifedipine plus propranolol, and at atrial pacing the following results were obtained: left ventricular peak systolic pressure was reduced from $200 \pm 39$ to $157 \pm 30 \mathrm{mmHg}$; a positive correlation was found between the pre-drug left ventricular end-diastolic pressure and the magnitude of reduction in left ventricular end-diastolic pressure; systolic blood pressure was reduced from $125 \pm 31$ to $111 \pm 27 \mathrm{mmHg}$, and total peripheral resistance was reduced from $1403 \pm 307$ to $1160 \pm 209$ dyne $\mathrm{s}^{-1} \mathrm{~cm}^{-5}$. The combined administration reduced the resting left ventricular outflow gradient from $76 \pm 19$ to $45 \pm 26 \mathrm{mmHg}$, while cardiac index was left unchanged. The effects on mean pulmonary arteriolar resistance and mean pulmonary arteriolar and mean pulmonary capillary venous pressure were in most cases slight and insignificant. The results indicate an improved haemodynamic condition in patients with hypertrophic obstructive cardiomyopathy after the combined administration of nifedipine and propranolol: a treatment that might provide a new and useful alternative to already existing medication.

Drugs depresssing myocardial contractility should diminish the degree of left ventricular outflow obstruction in patients with hypertrophic obstructive cardiomyopathy, ${ }^{1}$ and medical treatment of this disorder with beta adrenergic receptor blockers has been in use for many years. While propranolol reduces left ventricular outflow (LV-Ao) gradient at rest, on exercise, and during isoprenaline infusion, ${ }^{2}$ and improves exercise performance, ${ }^{3}$ and relieves the symptoms of angina pectoris, ${ }^{4-6}$ the drug neither reduces the incidence of asymptomatic ventricular arrhythmias nor the risk of sudden death. ${ }^{7-9}$ Calcium antagonists such as verapamil and nifedipine depress contractile force by inhibiting transmembrane calcium influx during excitation. 10-12 Hereditary hamster cardiomyopathy is thought to be the result of a membrane disease, and abnormal calcium flux probably plays a prominent role in its pathogenesis. ${ }^{13}$ The possible relation between this cardiomyopathy and hypertrophic obstructive cardiomyopathy has been discussed. ${ }^{14}$ It has been shown that calcium antagonistic drugs, and, to a lesser extent, beta adrenergic receptor

Accepted for publication 23 February 1982 blockers are able to prevent the development of heart lesions in hamsters with hereditary cardiomyopathy. ${ }^{13}$ Recently, it has been reported that the calcium antagonistic drug verapamil reduces the resting left ventricular outflow gradient, increases the heart rate and cardiac output, and lowers systolic blood pressure in patients with hypertrophic obstructive cardiomyopathy. ${ }^{15}$ With long term treatment by this drug exercise tolerance increased, and heart size, QRS complex amplitude, left ventricular outflow gradient, free wall thickness, and left ventricular diameter were reduced. 1617 The conclusion drawn from one of these studies was that verapamil is superior to beta blockers in hypertrophic obstructive cardiomyopathy. ${ }^{16}$

By reducing the entry of calcium ions into smooth muscle cells, calcium antagonists reduce blood pressure and total peripheral resistance, thereby inducing a reflex sympathetic stimulation of the heart. ${ }^{18-20}$ This effect, which is presumed to be present even during chronic administration of nifedipine, 2122 will probably, to a certain extent, counteract the negative inotropic action of the drugs. ${ }^{23} \mathrm{~A}$ more rational way to treat patients with hypertrophic obstructive car- 
diomyopathy would be to combine a calcium antagonist with a beta adrenergic receptor blocker. Verapamil increases atrioventricular nodal conduction time and refractoriness, ${ }^{24}$ and a pronounced and dose related increase in PR interval after this drug has been found in patients with hypertrophic obstructive cardiomyopathy. ${ }^{15}$ In addition, sinus arrest and sinus bradycardia associated with oral verapamil treatment have been described in $2 \%$ and $11 \%$ of these patients, respectively. ${ }^{25}$ Because of the tendency to produce atrioventricular block, the combined administration of verapamil and a beta blocker is not recommended.26 27 On the other hand, nifedipine alone ${ }^{28} 29$ or in combination with a beta adrenergic receptor blocker has no detrimental effect on atrioventricular nodal function. 1930 This paper describes the acute haemodynamic changes in patients with hypertrophic obstructive cardiomyopathy induced by nifedipine, propranolol, and the combination of nifedipine and propranolol.

\section{Patients and haemodynamic measurements}

Twelve patients, six men and six women, aged 26 to 67 years (mean 45 years) participated in the study. Before catheterisation a tentative diagnosis of hypertrophic obstructive cardiomyopathy was made on the basis of symptoms, physical examination, and electrocardiographic and echocardiographic abnormalities. The patients were all in normal sinus rhythm. Informed consent was obtained from all. All cardiac medication was discontinued at least three days before catheterisation.

The investigation was carried out with the patients supine and fasted. They were premedicated with $0.1 \mathrm{~g}$ aprobarbitone. Right heart catheterisation was performed with a Swan-Ganz thermodilution catheter advanced to the pulmonary artery, and a pacemaker electrode was placed in the right atrium. Cardiac output was measured at least in duplicate by thermodilution. Mean pulmonary arteriolar $(\overline{\mathrm{PA}})$ and mean pulmonary capillary venous pressure $(\overline{\mathrm{PCV}})$ were obtained by electrical integration recorded on a Mingograph 82 (Elema-Schönander, Stockholm, Sweden). Left ventricular peak systolic pressure (LVPSP) and left ventricular end-diastolic pressure (LVEDP) were obtained through an end-hole catheter (multipurpose side-holes, F. 8, Ducor) placed in the apex of the left ventricle by the retrograde femoral technique. The left ventricular-aortic pressure (LV-Ao) gradient was measured by slowly withdrawing the catheter from the apex of the ventricle to the aortic root. Particular care was taken in order to avoid its entrapment. Changes in heart rate induced by exercise, isoprenaline infusion, and atrial pacing may change the left ventricular outflow gradient and left ventricular end-diastolic pressure in patients with hypertrophic obstructive cardiomyopathy ${ }^{2} 31$ and, in order to eliminate rate dependent haemodynamic changes, all recordings were performed at an atrial pacing rate about 20 beats above the heart rate in the control period. The patients were then randomised into two groups.

Patients in group 1 were first given nifedipine 20 $\mathrm{mg}$ to chew in the mouth and the recordings were repeated 30 minutes later. Propranolol, $5 \mathrm{mg}$ intravenously over five minutes, was then given, and the measurements were repeated 10 minutes after the end of the injection.

Patients in group 2 were given the propranolol first, $5 \mathrm{mg}$ intravenously with measurements 10 minutes later, and then the $20 \mathrm{mg}$ of nifedipine to chew with repeat measurements 30 minutes later.

CALCULATIONS AND STATISTICAL ANALYSIS

Pulmonary arteriolar resistance

$(\mathrm{PAR})=\frac{\overline{\mathrm{PA}}-\overline{\mathrm{PCV}}}{\mathrm{CO}} \times 80$ dyne s$^{-1} \mathrm{~cm}^{-5}$

$\left.\begin{array}{l}\text { Mean aortic } \\ \text { pressure }(\overline{\mathrm{Ao}})\end{array}\right)=\frac{\text { systolic }}{\mathrm{BP}+2 \times \text { diastole } \mathrm{BP}(\mathrm{mmHg})} \underset{3}{3}$

Total peripheral

resistance $(\mathrm{TPR})=\frac{\mathrm{Ao}}{\mathrm{CO}} \times 80$ dynes $^{-1} \mathrm{~cm}^{-5}$

Cardiac index $(\mathrm{CI})=\frac{\mathrm{CO}(1 / \mathrm{min})}{\text { Total body surface }\left(\mathrm{m}^{2}\right)}$

The results are expressed as mean \pm SD. Student's $t$ test for paired comparison was used when observations before were compared with those after the drugs. Differences were regarded as significant when $\mathrm{p} \leqq 0.05$.

\section{Results}

The spontaneous heart rate for the whole group of patients in the control period was $76 \pm 14$ beats/ minutes (Table 1). Neither nifedipine, propranolol, nor the combined administration of the two drugs significantly changed mean heart rate (Table 1). While nifedipine alone, however, tended to increase heart rate, propranolol and the combined administration tended to decrease it (Table 1).

With atrial pacing, nifedipine and propranolol lowered left ventricular peak systolic pressure in most cases, and the combined administration of the two drugs significantly reduced left ventricular peak systolic pressure for the whole group of patients from $200 \pm 39$ to $157 \pm 30 \mathrm{mmHg}(\mathrm{p}<0.001)$ (Table 1, Fig. 1).

Eight out of 12 patients had a left ventricular enddiastolic pressure in the control period above the normal limit $(>12 \mathrm{mmHg})$. Neither the separate administration of nifedipine, propranolol, nor the 
Table 1 Haemodymamic measurements in control period $(C)$, after nifedipine $(N)$, propranolol $(P)$, and the combined administration of nifedipine and propranolol $(N+P, P+N)$

\begin{tabular}{|c|c|c|c|c|c|c|c|c|c|c|c|c|c|}
\hline \multirow[b]{2}{*}{ Heart rate (beats/min) } & \multicolumn{2}{|c|}{$\begin{array}{l}C_{1} \\
\text { (6 patients) }\end{array}$} & \multicolumn{2}{|l|}{$N$} & \multirow{2}{*}{$\begin{array}{c}N+P \\
\begin{array}{c}66 \\
(6)\end{array}\end{array}$} & \multicolumn{2}{|c|}{$\begin{array}{l}C_{2} \\
\text { (6 patients) }\end{array}$} & \multicolumn{2}{|l|}{$\boldsymbol{P}$} & \multirow{2}{*}{$\begin{array}{c}P+N \\
70 \\
(10)\end{array}$} & \multicolumn{2}{|c|}{$\begin{array}{l}C_{1}+C_{2} \\
\text { (12 patients) }\end{array}$} & \multirow{2}{*}{$\begin{array}{c}N+P \\
68 \\
(8)\end{array}$} \\
\hline & $\begin{array}{c}73 \\
(18)\end{array}$ & NS & $\begin{array}{c}81 \\
(16)\end{array}$ & $\star$ & & $\begin{array}{c}79 \\
(9)\end{array}$ & NS & $\begin{array}{c}70 \\
(13)\end{array}$ & NS & & $\begin{array}{c}76 \\
(14)\end{array}$ & NS & \\
\hline LVPSP (mmHg) & 197 & $\star \star$ & 180 & NS & $\begin{array}{l}153 \\
(37)\end{array}$ & 203 & NS & $\begin{array}{l}179 \\
(36)\end{array}$ & NS & 161 & 200 & $\star \star \star \star$ & $\begin{array}{l}157 \\
(30)\end{array}$ \\
\hline LVEDP (mmHg) & $\begin{array}{l}\text { (J) } \\
17 \\
(10)\end{array}$ & NS & $\begin{array}{l}(01) \\
17 \\
(6)\end{array}$ & NS & $\begin{array}{l}12 \\
12 \\
(3)\end{array}$ & $\begin{array}{l}(19) \\
17 \\
(4)\end{array}$ & NS & $\begin{array}{l}(30) \\
15 \\
(5)\end{array}$ & $\star$ & $\begin{array}{c}17 \\
17 \\
(2)\end{array}$ & $\begin{array}{l}(39) \\
17 \\
(7)\end{array}$ & NS & $\begin{array}{l}15 \\
(4)\end{array}$ \\
\hline $\mathrm{SBP}(\mathrm{mmHg})$ & $\begin{array}{l}127 \\
(40)\end{array}$ & NS & $\begin{array}{l}123 \\
(48)\end{array}$ & NS & $\begin{array}{l}112 \\
(32)\end{array}$ & $\begin{array}{l}123 \\
(21)\end{array}$ & NS & $\begin{array}{l}122 \\
(19)\end{array}$ & * & $\begin{array}{l}108 \\
(23)\end{array}$ & $\begin{array}{l}125 \\
(31)\end{array}$ & $\star$ & $\begin{array}{l}111 \\
(27)\end{array}$ \\
\hline TPR (dyne $\mathrm{s}^{-1} \mathrm{~cm}^{-5}$ ) & $\begin{array}{l}1413 \\
(310)\end{array}$ & $\star \star$ & $\begin{array}{l}1050 \\
(217)\end{array}$ & $\star \star$ & $\begin{array}{l}1138 \\
(252)\end{array}$ & $\begin{array}{l}1393 \\
(333)\end{array}$ & NS & $\begin{array}{c}1598 \\
(276)\end{array}$ & $\star \star$ & $\begin{array}{l}1182 \\
(179)\end{array}$ & $\begin{array}{l}1403 \\
(307)\end{array}$ & $\star \star$ & $\begin{array}{l}1160 \\
(209)\end{array}$ \\
\hline LV-Ao gradient (mmHg) & $\begin{array}{r}70 \\
(17)\end{array}$ & NS & $\begin{array}{r}54 \\
(35)\end{array}$ & NS & $\begin{array}{c}38 \\
(23)\end{array}$ & $\begin{array}{l}81 \\
(22)\end{array}$ & $\star$ & $\begin{array}{c}57 \\
(30)\end{array}$ & NS & $\begin{array}{c}52 \\
(30)\end{array}$ & $\begin{array}{l}76 \\
(19)\end{array}$ & $\star \star \star \star$ & $\begin{array}{c}45 \\
(26)\end{array}$ \\
\hline
\end{tabular}

Asterisks indicate those values that are significantly different $\left({ }^{\star} p<0.05 ;{ }^{\star \star} p<0.01 ;{ }^{\star \star \star} p<0.001\right)$; NS, not significant. SD in parentheses. LVPSP, left ventricular peak systolic pressure; LVEDP, left ventricular end-diastolic pressure; SBP, systolic blood pressure; TPR, total peripheral resistance; LV-Ao, left ventricular outflow.

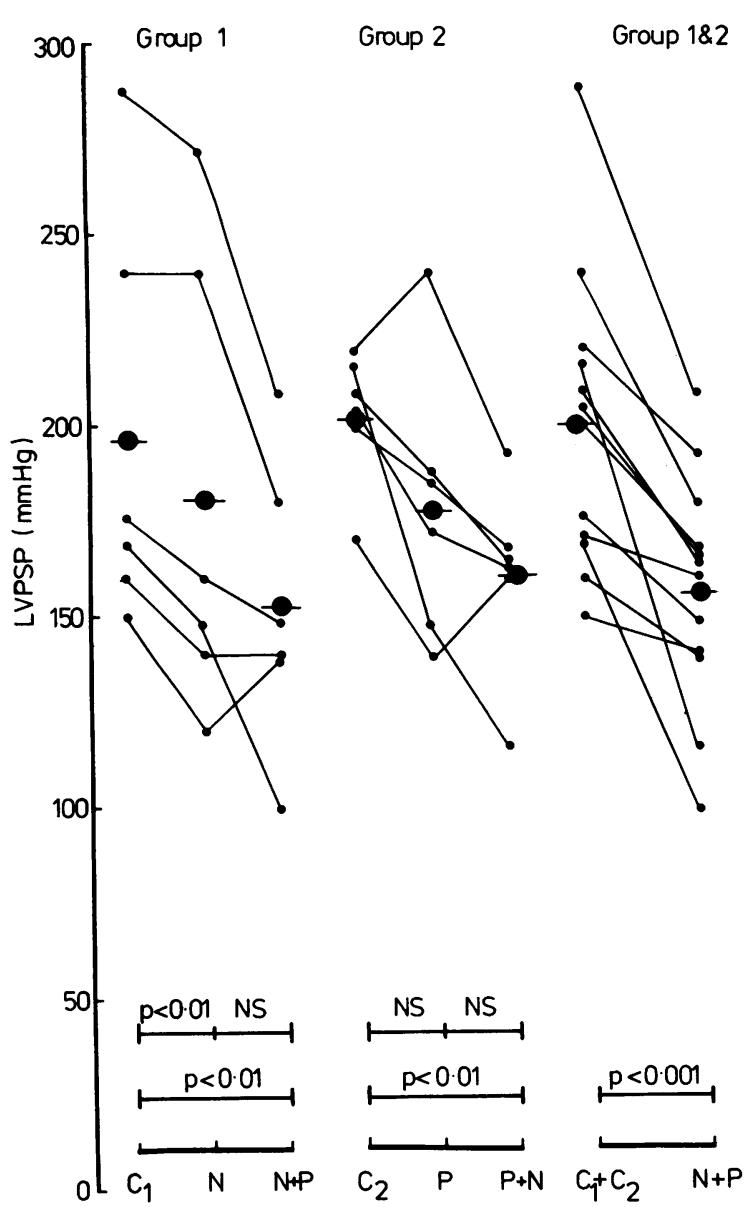

Fig. 1 Effect of nifedipine $(N)$ and propranolol $(P)$ on left ventricular peak systolic pressure (LVPSP). NS, not significant. combined administration of the two drugs significantly changed it (Table 1, Fig. 2); after the combined administration of nifedipine and propranolol, however, the fall in left ventricular enddiastolic pressure ( $\triangle$ LVEDP) was significantly correlated to the pre-drug values (Fig. 3). In the group of six patients initially given nifedipine, the only patient with a very high left ventricular end-diastolic pressure had the filling pressure definitely reduced; in the remaining five patients in whom it was normal or slightly raised, the values were essentially unchanged after the drug was given (Fig. 3).

Systolic blood pressure did not change after the initial administration of nifedipine (Table 1, Fig. 4). Intravenous injection of propranolol to patients not pretreated with nifedipine did not reduce systolic blood pressure (Table 1). The combined administration of the two drugs, however, significantly reduced systolic blood pressure for the whole group $(p<0.05)$ (Table 1, Fig. 4). Nifedipine reduced total peripheral resistance in all patients, propranolol increased it in most patients; the combined administration, on the other hand, reduced it in all but one, and to a significant degree $(p<0.01)$ (Table 1, Fig. 5).

The pretreatment resting left ventricular outflow gradient was $76 \pm 19 \mathrm{mmHg}$ (range 50 to $114 \mathrm{mmHg}$ ) (Table 1). While the separate administration of nifedipine or propranolol reduced the gradient in the majority of patients, the reducing effect of the combined administration was much more significant (Table 1, Fig. 6). In one patient, the gradient increased after the initial administration of nifedipine (from 96 to $120 \mathrm{mmHg}$ ), with a simultaneous reduction in systolic blood pressure from 144 to 120 mmHg; after the combined administration, on the other hand, the gradient fell to $80 \mathrm{mmHg}$ (Fig. 6).

Whereas nifedipine significantly increased cardiac index, propranolol reduced it in most cases; the com- 

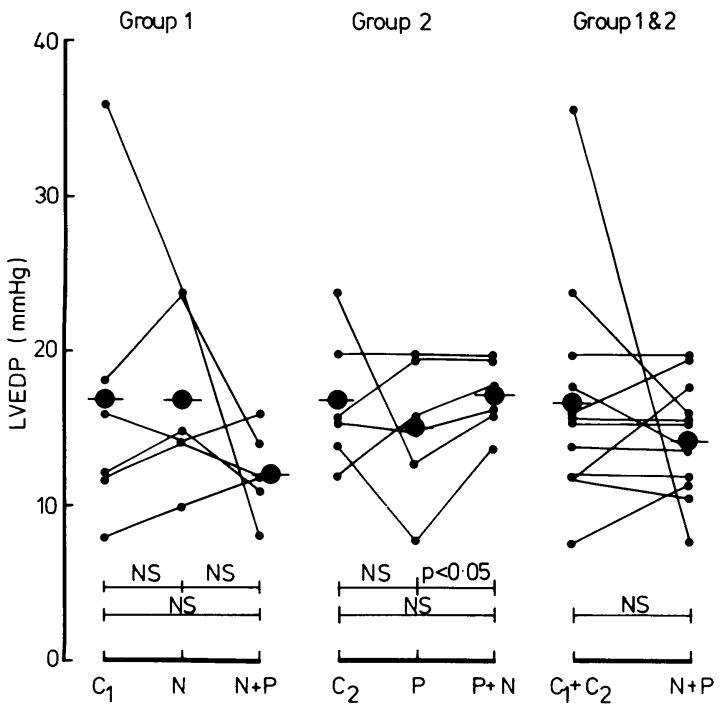

Fig. 2 Effect of nifedipine $(N)$ and propranolol $(P)$ on left ventricular end-diastolic pressure (LVEDP). NS, not significant.

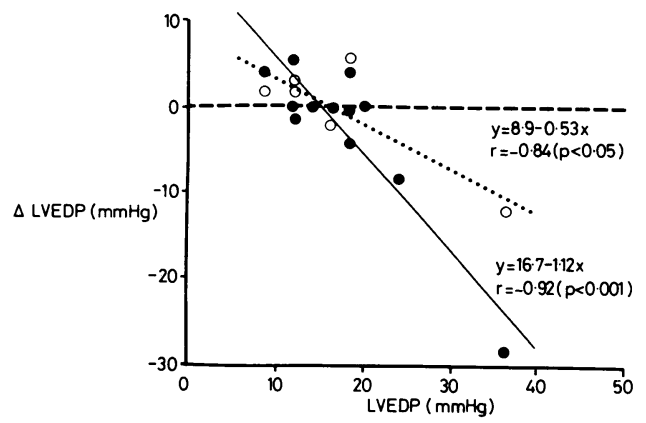

Fig. 3 Relation between control left ventricular end-diastolic pressure (LVEDP) and change in LVEDP ( $\triangle L V E D P)$ after nifedipine (open circles, interrupted line), and the combined treatment with nifedipine and propranolol (closed circles, solid line).

bined administration caused a slight and statistically insignificant increase (Table 2, Fig. 7). The individual increases or decreases in cardiac index induced by the separate or combined administration of the drugs were, with few exceptions, associated with a fall or an increase in total peripheral resistance, respectively (Fig. 8).

Mean pulmonary arteriolar pressure was slightly but significantly increased by the combined administration of nifedipine and propranolol (Table 2). Neither nifedipine, propranolol, nor the combined administration of the two drugs significantly changed mean pulmonary arteriolar resistance and mean pulmonary capillary venous pressure (Table 2 ).

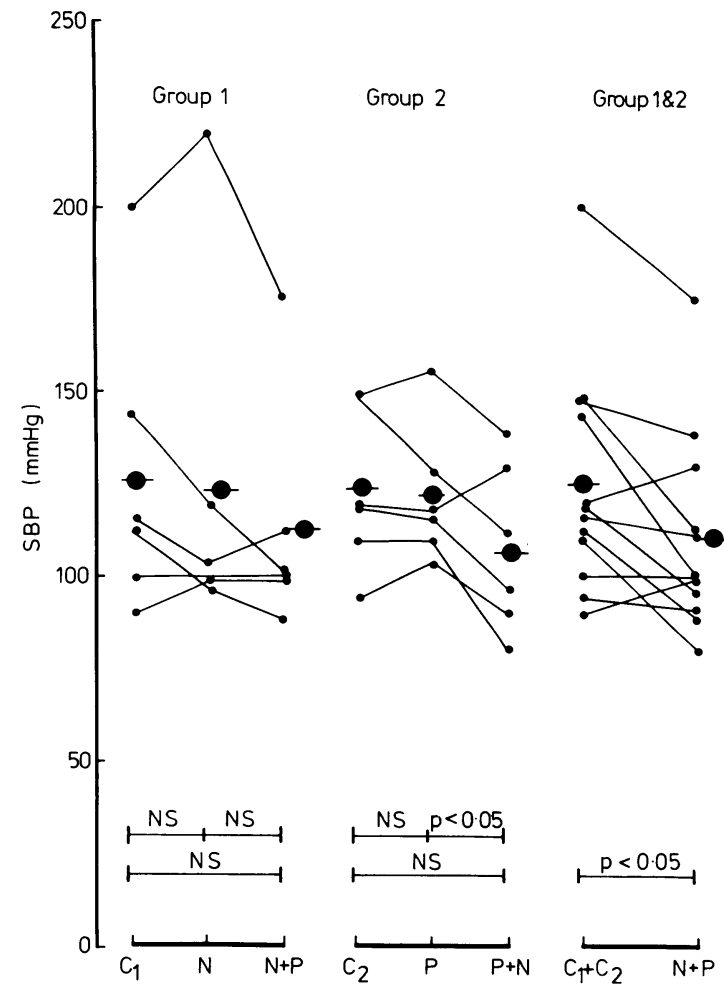

Fig. 4 Effect of nifedipine $(N)$ and propranolol $(P)$ on systolic blood pressure (SBP). Symbols as in Fig. 2.

The PR interval on the surface electrocardiogram was neither changed by nifedipine, propranolol, nor by the combined administration of the two drugs.

\section{Discussion}

The increase in heart rate induced by nifedipine in most of our patients is caused by a baroreceptor mediated activation of the sympathetic tone, ${ }^{20} 32$ an effect that could be completely blocked by intravenous administration of propranolol.

The fall in left ventricular peak systolic pressure after nifedipine is in accordance with previous reports. ${ }^{23} 3334$ This fall was more pronounced when the drug was combined with propranolol. The hypercontractile state in hypertrophic obstructive cardiomyopathy has been related to myocardial calcium overload, 81516 resulting from an abnormality of the cell membrane ${ }^{8}$ and/or an increased and abnormal sensitivity to catecholamines, ${ }^{35}$ which in that way augments calcium influx. ${ }^{36-38}$

The majority of the patients had raised left ventricular end-diastolic pressures, consistent with earlier reports on patients with hypertrophic obstructive cardiomyopathy. ${ }^{31}$ Prolonged left ventricular isovolumic 


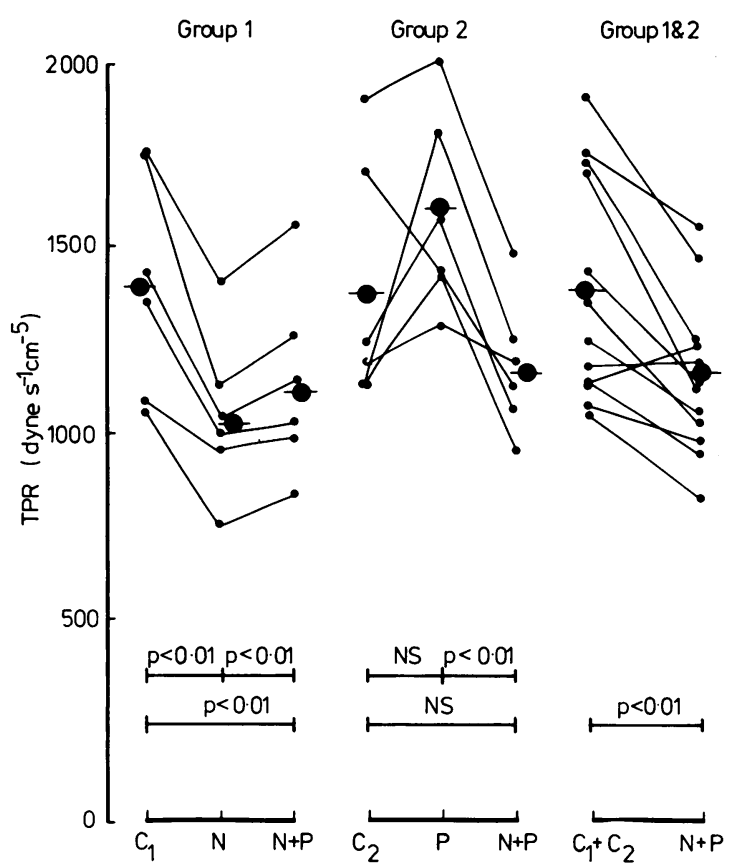

Fig. 5 Effect of nifedipine $(N)$ and propranolol $(P)$ on total peripheral resistance (TPR). Symbols as in Fig. 1.

relaxation time, together with an impaired diastolic filling, have also been shown in patients with this malady. ${ }^{39}{ }^{40}$ It has been suggested that the raised left ventricular end-diastolic pressure not only reflects the severity of the disease, but is the main determinant of symptoms and prognosis. ${ }^{41}$ While isoprenaline lowers left ventricular end-diastolic pressure in normal individuals as well as in patients with heart disease other than hypertrophic obstructive cardiomyopathy, ${ }^{42}$ it has been shown that left ventricular end-diastolic pressure increases after isoprenaline in most patients with that disease. ${ }^{31}$ In addition, the administration of isoprenaline to patients with hypertrophic obstructive cardiomyopathy always increases the obstruction to left ventricular outflow and muscular exercise often increases it. ${ }^{2}$ Our results indicate that nifedipine alone, and in particular the combined administration of nifedipine and propranolol, may improve left ventricular filling and compliance in those patients with increased left ventricular end-diastolic pressure. Recently it has been reported that left ventricular isovolumic relaxation time in hypertrophic obstructive cardiomyopathy was favourably shortened by the administration of nifedipine, 10 to $20 \mathrm{mg}$ sublingually. ${ }^{43}$ Though left-sided filling pressure rose after verapamil in a number of patients with hypertrophic obstructive cardiomyopathy, this phenomenon occurred mainly in patients who had normal pressures in the control period. ${ }^{15}$

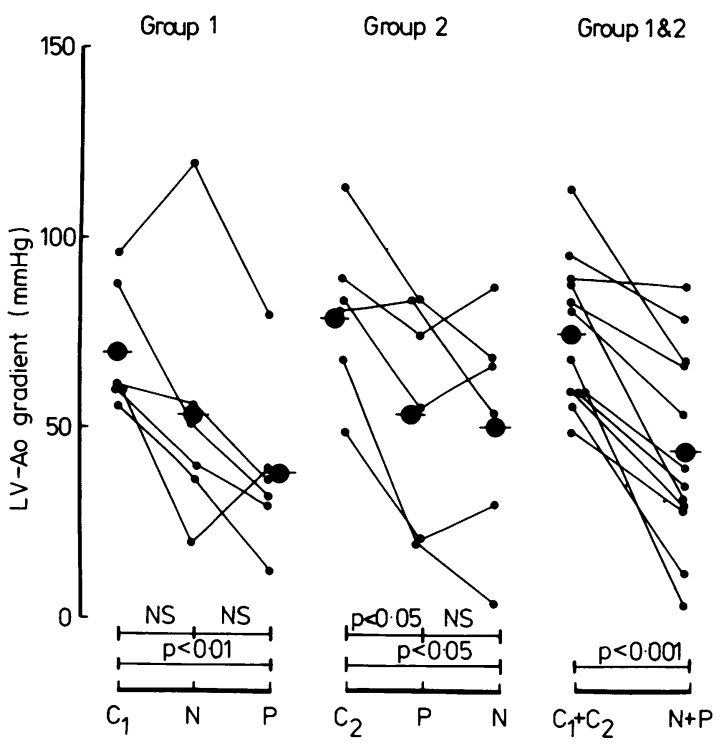

Fig. 6 Effect of nifedipine $(N)$ and propranolol $(P)$ on resting left ventricular outfow (LV-Ao) gradient. Symbols as in Fig. 1 and 2.

The effects of nifedipine and the combined administration of nifedipine and propranolol on systolic blood pressure and total peripheral resistance are in accordance with previous observations. ${ }^{20} 3244$

The effects of nifedipine and propranolol and the combination of the two drugs on mean pulmonary arteriolar resistance and mean pulmonary arteriolar and mean pulmonary capillary venous pressure were in most cases slight and insignificant.

Whereas the separate administration of nifedipine and propranolol reduced left ventricular outflow gradient in most patients, the combined administration of the two drugs caused a more pronounced and general reduction in the gradient in all patients. Any changes in the gradient result from alterations in left ventricular peak systolic pressure and systolic blood pressure. It has been suggested that reduction in systolic blood pressure and total peripheral resistance may increase the left ventricular outflow gradient in patients with hypertrophic obstructive cardiomyopathy, ${ }^{45}$ and in one patient this was found after nifedipine. The combined administration, however, reduced the gradient slightly in comparison with the control value.

The nifedipine-induced increase in cardiac index during atrial pacing found in our study is consistent with a previous report. ${ }^{32}$ Even in combination with propranolol, which by itseff reduces cardiac index, ${ }^{2}$ eight out of 12 patients were able to increase their cardiac index in relation to the control values. As heart rate was kept constant by atrial pacing, it is 
Table 2 Haemodynamic measurements in control period $(C)$, after nifedipine $(N)$, propranolol $(P)$, and combined administration of nifedipine and propranolol $(N+P, P+N)$

\begin{tabular}{|c|c|c|c|c|c|c|c|c|c|c|c|c|c|}
\hline \multirow[b]{2}{*}{ CI $\left(1 / \min\right.$ per $\left.\mathrm{m}^{2}\right)$} & \multicolumn{2}{|c|}{$\begin{array}{l}C_{1} \\
\text { (6 patients) }\end{array}$} & \multicolumn{2}{|l|}{$N$} & \multirow{2}{*}{$\begin{array}{c}N+P \\
3.3 \\
(0.5)\end{array}$} & \multicolumn{2}{|c|}{$\begin{array}{l}C_{2} \\
\text { (6 patients) }\end{array}$} & \multicolumn{2}{|l|}{$P$} & \multirow[t]{2}{*}{$P+N$} & \multicolumn{2}{|c|}{$\begin{array}{l}C_{1}+C_{2} \\
\text { (12 patients) }\end{array}$} & \multirow{2}{*}{$\begin{array}{c}N+P \\
\begin{array}{c}3.2 \\
(0.3)\end{array}\end{array}$} \\
\hline & $\begin{array}{c}3.0 \\
(0.5)\end{array}$ & $\star \star$ & $\begin{array}{c}3.5 \\
(0.5)\end{array}$ & $\star \star$ & & $\begin{array}{c}3.1 \\
(0.3)\end{array}$ & NS & $\begin{array}{c}2.8 \\
(0.7)\end{array}$ & $\star \star$ & & $\begin{array}{c}3.0 \\
(0.3)\end{array}$ & NS & \\
\hline$\overline{\mathrm{PA}}(\mathrm{mmHg})$ & $\begin{array}{l}19 \\
(7)\end{array}$ & NS & $\begin{array}{l}21 \\
(9)\end{array}$ & NS & $\begin{array}{l}21 \\
(10)\end{array}$ & $\begin{array}{l}15 \\
(6)\end{array}$ & NS & $\begin{array}{l}16 \\
(6)\end{array}$ & * & $\begin{array}{l}19 \\
(6)\end{array}$ & $\begin{array}{l}17 \\
(7)\end{array}$ & * & 20 \\
\hline$\overline{\mathrm{PCV}}(\mathrm{mmHg})$ & $\begin{array}{l}12 \\
(6)\end{array}$ & NS & $\begin{array}{l}15 \\
(8)\end{array}$ & NS & $\begin{array}{l}14 \\
(8)\end{array}$ & $\begin{array}{l}10 \\
(5)\end{array}$ & NS & 11 & NS & $\begin{array}{l}12 \\
(5)\end{array}$ & 11 & NS & $\begin{array}{l}13 \\
(7)\end{array}$ \\
\hline PAR (dyne $\mathrm{s}^{-1} \mathrm{~cm}^{-5}$ ) & $\begin{array}{l}102 \\
(64)\end{array}$ & NS & $\begin{array}{c}80 \\
(29)\end{array}$ & NS & $\begin{array}{l}102 \\
(53)\end{array}$ & $\begin{array}{c}82 \\
(30)\end{array}$ & NS & $\begin{array}{l}102 \\
(42)\end{array}$ & NS & $\begin{array}{c}87 \\
(30)\end{array}$ & $\begin{array}{c}92 \\
(49)\end{array}$ & NS & $\begin{array}{c}95 \\
(42)\end{array}$ \\
\hline
\end{tabular}

Asterisks indicate those values that are significantly different $\left({ }^{\star} \mathrm{p}<0.05 ;{ }^{\star \star} \mathrm{p}<0.01\right)$; NS, not significant. SD in parentheses. CI, cardiac index; $\overline{\mathrm{PA}}$, mean pulmonary arteriolar pressure; $\mathrm{PCV}$, mean pulmonary capillary venous pressure; PAR, pulmonary arteriolar resistance.

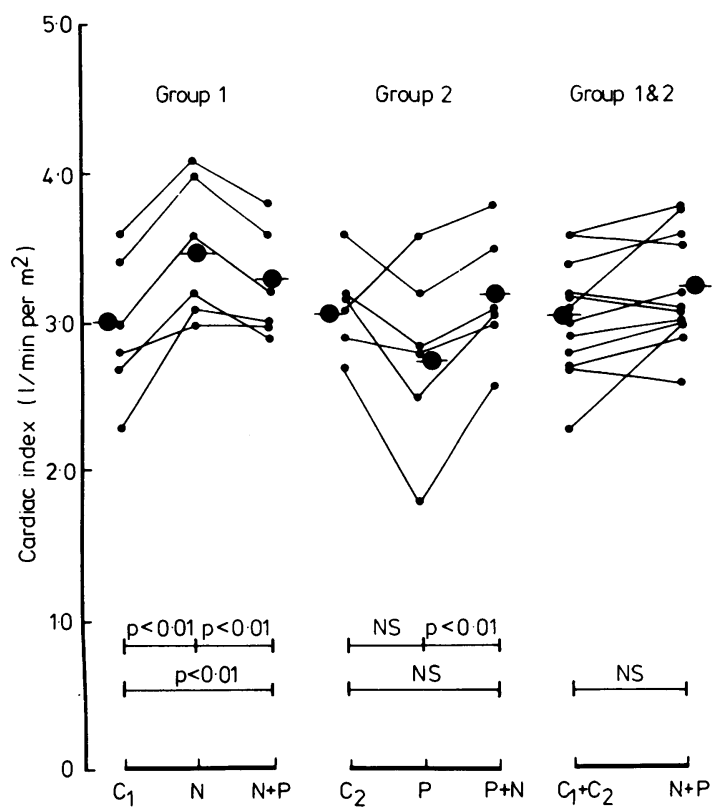

Fig. 7 Effect of nifedipine $(N)$ and propranolol $(P)$ on cardiac index. Symbols as in Fig. 1 .

probable that the increase in cardiac index observed in all patients after nifedipine and in most patients after the combined administration of both drugs was mainly the result of a reduction in total peripheral resistance (afterload). Even in the patient where the left ventricular outflow gradient increased after nifedipine, a rise of cardiac index from 3.0 to $3.6 \mathrm{l} / \mathrm{min}$ per $\mathrm{m}^{2}$ was found.

The lowering of left ventricular peak systolic pressure, systolic blood pressure, and left ventricular outflow gradient in the presence of a maintained cardiac index will reduce myocardial oxygen needs and have a favourable effect on the balance between myocardial oxygen supply and demand and also prevent the vicious cycle of obstruction hypertrophy. ${ }^{2}$ In this acute haemodynamic study, the combined

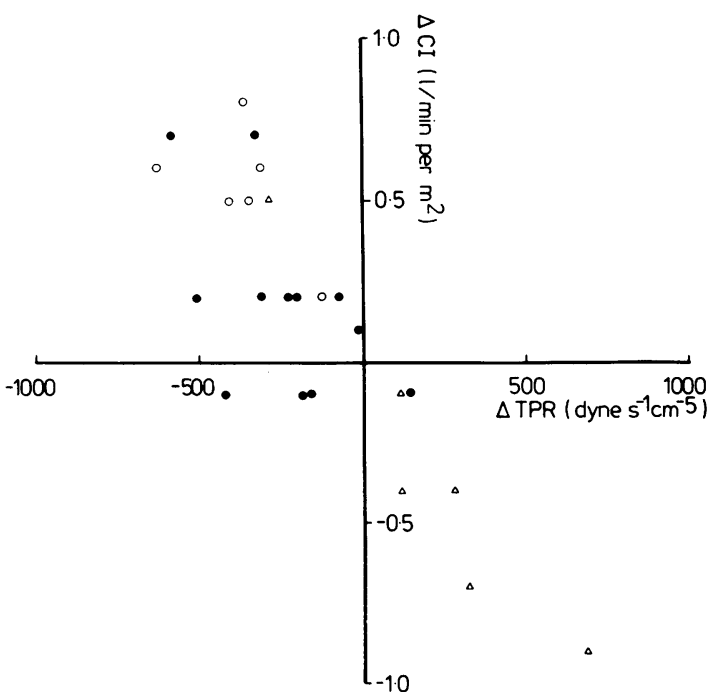

Fig. 8 Relation between the changes in total peripheral resistance $(\triangle T P R)$ and cardiac index $(\triangle C I)$ after nifedipine (open circles), propranolol (open triangles), and the combined administration of nifedipine and propranolol (closed circles).

administration of nifedipine and propranolol appeared to be superior to the separate administration of nifedipine, and the increased sympathetic tone secondary to nifedipine seemed to be well counteracted by beta adrenergic receptor blockade. The combined effects on left ventricular peak systolic pressure, systolic blood pressure, and left ventricular outflow gradients were more pronounced, cardiac index was in most patients maintained at higher levels than in the control period, total peripheral resistance was reduced, and left ventricular end-diastolic pressure was decreased in those patients having high control values. Since an extension of the study would be time consuming and also troublesome to the patients, druginduced haemodynamic changes were not measured at a spontaneous heart rate. The negative chronotropic 
action of the combined administration of nifedipine and propranolol will have a favourable effect on myocardial oxygen consumption. 46 No side effects were observed, and no disturbance in atrioventricular nodal function was noted.

Our results indicate that the combined administration of nifedipine and propranolol in hypertrophic obstructive cardiomyopathy provides a new alternative to already existing treatment.

\section{References}

1 Harrison DC, Braunwald E, Glick G, Mason DT, Chidsey CA, Ross J Jr. Effects of beta adrenergic blockade on - the circulation, with particular reference to observations in patients with hypertrophic subaortic stenosis. Circulation 1964; 29: 84-98.

2 Flamm MD, Harrison DC, Hancock EW. Muscular subaortic stenosis: prevention of outflow obstruction with propranolol. Circulation 1968; 38: 846-58.

3 Cohen LS, Braunwald E. Amelioration of angina pectoris in idiopathic hypertrophic subaortic stenosis with betaadrenergic blockade. Circulation 1967; 35: 847-51.

4 Adelman AG, Shah PM, Gramiak R, Wigle ED. Longterm propranolol therapy in muscular subaortic stenosis. Br Heart f 1970; 32: 804-11.

5 Edwards RHT, Kristinsson A, Warrell DA, Goodwin JF. Effects of propranolol on response to exercise in hypertrophic obstructive cardiomyopathy. $\mathrm{Br}$ Heart $\mathrm{f}$ 1970; 32: 219-25.

6 Hubner PJB, Ziady GM, Lane GK, et al. Double-blind trial of propranolol and practolol in hypertrophic cardiomyopathy. Br Heart f 1973; 35: 1116-23.

7 Hardarson T, de la Calzada CS, Curiel R, Goodwin JF. Prognosis and mortality of hypertrophic obstructive cardiomyopathy. Lancet 1973; ii: 1462-7.

8 Goodwin JF, Krikler DM. Arrhythmia as a cause of sudden death in hypertrophic cardiomyopathy. Lancet 1976; ii: 937-40.

9 McKenna WJ, Chetty S, Oakley CM, Goodwin JF. Arrhythmia in hypertrophic cardiomyopathy: exercise and $\mathbf{4 8}$ hour ambulatory electrocardiographic assessment with and without beta adrenergic blocking therapy. $A m \mathcal{F}$ Cardiol 1980; 45: 1-5.

10 Fleckenstein A. Specific inhibitors and promoters of calcium action in the excitation-contraction coupling of heart muscle and their role in the prevention or production of myocardial lesions. In: Harris P, Opie LH, eds. Calcium and the heart. London \& New York: Academic Press, 1971: 135-88.

11 Hashimoto $\mathrm{K}$, Taira N, Chiba S, et al. Cardiohemodynamic effects of BAY a 1040 in the dog. Arzneim Forsch 1972; 22: 15-21.

12 Refsum H. Calcium-antagonistic and antiarrhythmic effects of nifedipine on the isolated rat atrium. Acta Pharmacol Toxicol (Kbh) 1975; 37: 377-86.

13 Jasmin G, Proschek L. Prevention of myocardial degeneration in hamsters with hereditary cardiomyopathy. In: Fleckenstein A, Roskamm H, eds. Calciumantagonismus. Berlin, Heidelberg, \& New York: Springer-Verlag, 1980: 144-50.
14 Lossnitzer K, Konrad A, Jakob M. Kardioprotektion durch Kalzium-antagonisten bei erblich kardiomyopathischen Hamstern. In: Fleckenstein A, Roskamm H, eds. Calcium-antagonismus. Berlin, Heidelberg, \& New York: Springer-Verlag, 1980: 151-71.

15 Rosing DR, Kent KM, Borer JS, Seides SF, Maron BJ, Epstein SE. Verapamil therapy: a new approach to the pharmacologic treatment of hypertrophic cardiomyopathy. I. Hemodynamic effects. Circulation 1979; 60: 1201-7.

16. Kaltenbach M, Hopf R, Kober G, Bussmann W-D, Keller $M$, Petersen $Y$. Treatment of hypertrophic obstructive cardiomyopathy with verapamil. $\mathrm{Br}$ Heart $\mathcal{F}$ 1979; 42: 35-42.

17 Rosing DR, Kent KM, Maron BJ, Epstein SE. Verapamil therapy: a new approach to the pharmacologic treatment of hypertrophic cardiomyopathy. II. Effects on exercise capacity and symptomatic status. Circulation 1979; 60: 1208-13.

18 Atterhög J-H, Ekelund L-G. Haemodynamic effect of intravenous verapamil at rest and during exercise in subjectively healthy middleaged men. Eur $\mathcal{f}$ Clin Pharmacol 1975; 8: 317-22.

19 Ekelund L-G, Orö L. Antianginal efficiency of nifedipine with and without a beta-blocker, studied with exercise test. A double-blind, randomized subacute study. Clin Cardiol 1979; 2: 203-11.

20 Pedersen OL, Mikkelsen E. Acute and chronic effects of nifedipine in arterial hypertension. Eur $\mathcal{f}$ Clin Pharmacol 1978; 14: 375-81.

21 Pedersen OL, Mikkelsen E, Christensen NJ, Kornerup HJ, Pedersen EB. Effect of nifedipine on plasma renin, aldosterone and catecholamines in arterial hypertension. Eur f Clin Pharmacol 1979; 15: 235-40.

22 Pedersen OL, Mikkelsen E, Kornerup HJ, Christensen NJ. Effects of nifedipine on blood pressure, regional hemodynamics, plasma renin activity and plasma catecholamines in patients with arterial hypertension. Acta Med Scand 1979; 625, suppl: 65-7.

23 Serruys PW, van den Brand M, ten Katen HJ, Brower RW. Regional wall motion following intra-bypass injection of nifedipine: design of a protocol and initial experience. In: Fleckenstein A, Roskamm $\mathbf{H}$, eds. Calcium-antagonismus. Berlin, Heidelberg, \& New York: Springer-Verlag, 1980: 282-92.

24 Landmark K, Amlie JP. A study of the verapamilinduced changes in conductivity and refractoriness and monophasic action potentials of the dog heart in situ. Eur f Cardiol 1976; 4/4: 419-27.

25 Epstein SE, Rosing DR. Verapamil: its potential for causing serious complications in patients with hypertrophic cardiomyopathy. Circulation 1981; 64: 437-41.

26 Krikler D. Verapamil in cardiology. Eur $\mathcal{F}$ Cardiol 1974; 2/1: 3-10.

27 Henry PD. Comparative pharmacology of calcium antagonists: nifedipine, verapamil and diltiazem. $A m \boldsymbol{F}$ Cardiol 1980; 46: 1047-58.

28 Ekelund L-G, Atterhög J-H. Adalat and beta blockers: the mechanism studied with two series of work tests in two groups of patients with angina pectoris. In: Lochner W, Braasch W, Kroneberg G, eds. New therapy of ischemic heart disease. 2nd International Adalat symposium. 
Berlin, Heidelberg, \& New York: Springer-Verlag, 1975: 169-73.

29 Rowland E, Evans T, Krikler D. Effect of nifedipine on atrioventricular conduction as compared with verapamil. Intracardiac electrophysiological study. Br Heart $\mathcal{F} 1979$; 42: 124-7.

30 Amlie JP, Landmark $K$. The effect of nifedipine on the sinus and atrioventricular node of the dog heart after $\beta$-adrenergic receptor blockade. Acta Pharmacol Toxicol (Kbh) 1978; 42: 287-91.

31 Webb-Peploe MM, Croxson RS, Oakley CM, Goodwin JF. Cardio-selective beta-adrenergic blockade in hypertrophic obstructive cardiomyopathy. Postgrad Med $\mathcal{F}$ 1971 ; 47, suppl: 93-6.

32 Guazzi M, Olivari MT, Polese A, Fiorentini C, Magrini F, Moruzzi P. Nifedipine, a new antihypertensive with rapid action. Clin Pharmacol Ther 1977; 22: 528-32.

33 Lichtlen P. The influence of nifedipine on left ventricular and coronary dynamics at rest and during exercise in patients with coronary artery disease. In: Hashimoto $\mathbf{K}$, Kimura E, Kobayashi T, eds. Ist Intermational nifedipine "Adalat" symposium. Tokyo: University of Tokyo Press, 1975: 114-20.

34 Lorell BH, Paulus WJ, Grossman W, Wynne J, Cohn PF, Braunwald E. Improved diastolic function and systolic performance in hypertrophic cardiomyopathy after nifedipine. $N$ Engl f Med 1980; 303: 801-3.

35 Goodwin JF, Oakley CM. The cardiomyopathies. $\mathrm{Br}$ Heart $f$ 1972; 34: 545-52.

36 Shinebourne EA, Hess ML, White RJ, Hamer J. The effect of noradrenaline on the calcium uptake of the sarcoplasmic reticulum. Cardiovasc Res 1969; 3: 113-7.

37 Beeler GW Jr, Reuter H. Membrane calcium current in ventricular myocardial fibres. $\mathcal{P}$ Physiol (Lond) 1970; 207: 191-209.

38 Katz AM, Repke DI. Calcium-membrane interactions in the myocardium: effect of ouabain, epinephrine and 3',
5 -cyclic adenosine monophosphate. Am $\mathcal{F}$ Cardiol 1973; 31: 193-201.

39 Goodwin JF. Hypertrophic cardiomyopathy: a disease in search of its own identity. Am $\mathcal{F}$ Cardiol 1980; 45: 17780.

40 Hanrath P, Mathey DG, Siegert R, Bleifeld W. Left ventricular relaxation and filling pattern in different forms of left ventricular hypertrophy: an echocardiographic study. Am $\mathcal{F}$ Cardiol 1980; 45: 15-23.

41 Swan DA, Bell B, Oakley CM, Goodwin J. Analysis of symptomatic course and prognosis and treatment of hypertrophic obstructive cardiomyopathy. $\mathrm{Br} \mathrm{Heart} \mathcal{f}$ 1971; 33: 671-85.

42 Krasnow N, Rolett EL, Yurchak PM, Hood WB Jr, Gorlin R. Isoproterenol and cardiovascular performance. Am $\mathcal{F}$ Med 1964; 37: 514-25.

43 Lorell BH, Paulus W, Grossman W, Fulton MA, Wynne J, Cohn PF. Improved diastolic compliance in hypertrophic cardiomyopathy treated with nifedipine (abstract). Circulation 1980; 62, suppl III: 317.

44 Olivari MT, Bartorelli C, Polese A, Fiorentini C, Moruzzi P, Guazzi MD. Treatment of hypertension with nifedipine, a calcium antagonistic agent. Circulation 1979; 59: 1056-62.

45 Wigle ED, David PR, Labrosse CJ, McMeekan J. Muscular subaortic stenosis. The interrelation of wall tension, outflow tract "distending pressure" and orifice radius. Am $\mathcal{F}$ Cardiol 1965; 15: 761-72.

46 Amsterdam EA, Hughes JL, De Maria AN, Zelis R, Mason DT. Indirect assessment of myocardial oxygen consumption in the evaluation of mechanisms and therapy of angina pectoris. Am $\mathcal{F}$ Cardiol 1974; 33: 73743.

Requests for reprints to Dr Knud Landmark, Lovisenberg Hospital, Lovisenberggt. 17, Oslo 4, Norway. 